\title{
Pengembangan Media Video Pembelajaran Fisika berbahasa Kaili pada Materi Besaran Fisika dan Pengukurannya
}

\author{
Development of Kaili-language Physics Learning Video Media on Physics and \\ Measurement Materials
}

\author{
Nur'azni, A. Hatibe, dan S. Saehana* \\ Program Studi Pendidikan Fisika FKIP Universitas tadulako, Palu, Indonesia \\ *e-mail: sahrulsaehana@gmail.com
}

\begin{tabular}{l}
\hline Article Info \\
\hline Article History: \\
Received: 30 April 2021 \\
Accepted: 21 Mei 2021 \\
Published: 31 Mei 2021 \\
Keywords: \\
Media Video \\
Pembelajaran Fisika \\
Bahasa Kaili \\
Besaran Fisika \\
Pengukuran \\
\end{tabular}

\begin{abstract}
The purpose of this study is to find out the activeness of students in the learning process by using video media learning physics in kaili language on the material of physics and its measurements for junior high school. This research includes a type of development research. This development uses the ADDIE model. The techniques used in data collection are questionnaires and observations. This development research process is carried out in several stages. The stages are: Analysis, Design, Development, Implementation, and Evaluation. The subject of the study for feasibility trials Of physics learning video in kaili language was conducted on students of grade VIID Hasanudin numbering 20 people at SMPN 1 Sindue. 1) Product feasibility trials are conducted by giving questionnaires in the form of questionnaires containing things related to the level of feasibility of video media learning physics in kaili language as a learning medium. The assessment results in students were obtained on average by 3.63 with the achievement of "Strongly agree". 2) Then the next trial was conducted on 10 students in the experimental class and 10 students in the control class. The assessment results in the experiment class averaged 3.44 and the control class averaged 3.39. Based on the data, kaili language physics learning video deserves to be used as a learning medium.
\end{abstract}

\section{PENDAHULUAN}

Desa Toaya merupakan daerah yang berada di wilayah Kabupaten Donggala Provinsi Sulawesi Tengah. Desa Toaya merupakan desa yang hampir seluruh masyarakatnya tersebut masih menggunakan bahasa kaili dialeg rai sebagai alat komunikasi sehari-hari, bahkan menjadi alat komunikasi di sekolah ketika proses belajar mengajar sedang berlangsung.

Bahasa kaili adalah salah satu bahasa daerah dari berbagai macam bahasa yang ada di Indonesia. Bahasa Kaili terdiri atas bermacam dialeg seperti dialeg rai, ledo, unde, da'a, ija, tara, dan dialeg doi. Bahasa Kaili dialeg rai sama halnya dengan bahasa daerah yang ada di persada Nusantara ini, mempunyai banyak fungsi, diantaranya dipergunakan sebagai bahasa di Sekolah-sekolah, dipergunakan sebagai alat komunikasi dalam pergaulan dan alat penghubung dalam keluarga dan masyarakat, khususnya penutur bahasa Kaili dialeg rai dan bahasa yang diturunkan secara turun temurun oleh nenek moyang suku kaili yang dulunya selalu menjaga dengan cara sering digunakan dalam berkomunikasi seharihari.
Widyhastuti [1], menyatakan bahasa merupakan salah satu unsur universal kebudayaan yang memungkinkan manusia untuk saling berkomunikasi dan berinteraksi dalam pergaulan sehari-hari. Pernyataan yang sejalan dengan pendapat Sarmin [2], berpendapat bahwa bahasa daerah sebagai bagian dari kebudayaan sangat bermanfaat bagi masyarakat pemakainya, terutama sebagai alat komunikasi sehingga memungkinkan terjadinya saling pengertian, saling sepakat, dan saling membutuhkan dalam kehidupan. Menyadari pentingnya bahasa daerah yang digunakan sebagai alat komunikasi dalam aspek-aspek kegiatan yang bersifat kedaerahan dan digunakan sebagai alat untuk mengembangkan suatu kebudayaan daerah.

Kalinda, dkk [3], mengatakan salah satu permasalahan pokok siswa dalam proses pembelajaran saat ini yaitu kesulitan siswa dalam menerima merespon serta mengembangkan materi yang diberikan oleh guru. Permasalahan diatas dipengaruhi oleh banyak faktor pada proses kegiatan belajar mengajar. Salah satu faktor yang mempengaruhi dalam proses kegiatan belajar mengajar ini adalah media pembelajaran yang digunakan oleh guru. 
Menurut Ayuningtyas, dkk [4], pembelajaran yang berkualitas memerlukan suatu perangkat pembelajaran yang dapat membantu siswa memahami dan menguasai materi Fisika dengan baik. Putra, dkk [5], mengatakan seiring dengan kemajuan dan berkembangnya teknologi di bidang komputer, maka kegiatan belajar mengajar dapat dikemas dalam suatu media pembelajaran yang menarik, sehingga siswa tidak monoton menerima materi yang disampaikan secara abstrak dari konsep yang disajikan.

Masalah yang sering ditemukan pada pembelajaran fisika adalah fisika dianggap kurang menarik dan kurang dipahami sebagai pelajaran hitungan, pemecahan persoalan fisika menggunakan persamaan matematika. Selain itu, materi yang disajikan oleh guru juga banyak yang bersifat abstrak dan rumit sehingga siswa enggan untuk mempelajarinya. Salah satu metode pembelajaran yang sangat berpengaruh kepada minat siswa adalah metode pembelajaran dengan penayangan video. Sehingga para guru banyak menggunakan media video pembelajaran.

Penyampaian materi melalui media video pembelajaran bukan cuma sekedar menyampaikan materi namun ada hal lain yang perlu diperhatikan dan dapat mempengaruhi minat siswa dalam belajar. Hal tersebut berupa pengalaman atau situasi yang mendukung dalam lingkungan sekitar, yaitu video tersebut dikemas dalam bahasa daerah (bahasa ibu), sehingga siswa akan lebih mudah dan tertarik lagi dalam pembelajaran dalam kelas, kemudian dibawakan ke dalam materi pelajaran yang disampaikan melalui video pembelajaran. Selain itu, dalam pelajaran peraktek siswa akan lebih mudah melakukan apa yang dilihatnya dalam vidio daripada materi yang disampaikan melalui buku atau gambar. Kegiatan seperti ini akan memudahkan siswa dan guru dalam proses belajar mengajar.

Mengingat banyaknya manfaat dari media video yang dapat dipergunakan untuk merangsang pikiran, perasaan, perhatian dan kemampuan atau ketrampilan belajar sehingga dapat memudahkan proses belajar siswa dan memudahkan guru dalam menyampaikan materi, juga dapat diulang kapan saja dengan materi yang sama dalam pembelajaran yang sama. Namun, dengan banyaknya media video pembelajaran yang ada, para guru masih menggunakan sedikit bahkan mungkin belum pernah ada yang menggunakan bahasa daerah (bahasa ibu) sebagai alat komunikasi untuk menjelaskan materi, untuk ditayangkan dalam video dan dijadikan cara agar materi yang disampaikan mudah diterima dan dipahami oleh siswa. Sehingga pada kesempatan ini, penulis ingin membuat media video pembelajaran dengan menggunakan bahasa ibu.

Bahasa ibu dikenal dengan bahasa sehari-hari yang biasa dipakai oleh anak-anak disekitar lingkungannya, sangat mudah dipelajari dan diikuti oleh mereka yang bergaul seusianya. Oleh karena saat bahasa ibu tersebut diaplikasikan dalam proses pembelajaran dalam kelas maka akan berpengaruh positif bagi siswa, yaitu siswa akan mudah memahami serta akan semakin tertarik ketika proses belajar mengajar berlangsung.

Sehingga kehadiran media video pembelajaran dengan bahasa daerah ini, diharapkan mampu menghilangkan kejenuhan siswa dalam belajar dan siswa lebih fokus dalam pembelajaran. Dalam proses pembelajaran, media memiliki kontribusi dalam meningkatkan mutu dan kualitas pengajaran. Kehadiran media tidak saja membantu pengajar dalam menyampaikan materi ajarnya, tetapi memberikan nilai tambahan pada kegiatan pembelajaran.

Pengembangan media pembelajaran ini diharapkan bermanfaat untuk siswa dalam memudahkan memahami materi besaran fisika dan pengukurannya, menjadi acuan guru-guru dalam usaha memperbaiki kualitas pembelajaran fisika dalam mengembangkan media ajarnya, serta dapat dijadikan tambahan referensi untuk penelitian selanjutnya tentang pengembangan media video pembelajaran fisika pokok bahasan lain.

\section{METODE PENELITIAN}

Penelitian ini termasuk jenis penelitian dan pengembangan atau dikenal Research and Developement (R\&D) yaitu model penelitian yang digunakan untuk menghasilkan produk tertentu, dan menguji keefektifan produk tersebut [7]. Penelitian yang dilakukan merupakan pengembangan bahan ajar mata kuliah fisika modern menggunakan model ADDIE. Model ADDIE terdiri dari lima tahapan yaitu analisis (analyse), perencanaan (design), pengembangan (development), pelaksanaan (implementation) dan evaluasi (evaluation).

Penelitian pengembangan bahan ajar ini menggunakan model ADDIE, Desain tersebut meliputi tahapan prosedur pengembangan produk dan uji produk yang perlu dilakukan secara umum dapat dilihat pada Gambar 2.

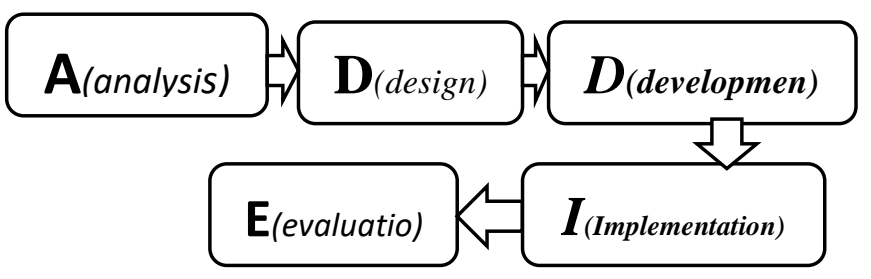

Gambar 1. Langkah-langkah metode ADDIE [6]

Langkah-langkah dalam penelitian ini penelitian hanya sampai pada tahap implementation. Dari gambar 2 maka langkah-langkah yang dilaksanakan meliputi:

1. Analysis

Analisis dalam penelitian ini meliputi analisis tujuan, analisis kurikulum, silabus, materi, analisis tingkat kemampuan dan karakteristik sasaran pengguna.

2. Design

Meliputi perancangan butir-butir materi, penyusunan alur penyampaian materi dalam bentuk flowchat, pembuatan story board, dan pengumpulan bahan-bahan yang dibutuhkan dalam pengembangan media video pebelajaran fisika berbahasa kaili. Proses ini adalah proses dimana gambaran awal dari media video pembelajaran fisika yang dikembangkan.

3. Development

Pada tahap ini media video pembelajaran fisika berbahasa kaili yang telah selesai dibuat kemudian melalui uji validasi oleh ahli materi, bahasa dan ahli desain. Uji validasi bertujuan untuk mengetahui validitas 
MEDIA EKSAKTA Vol. 17 No. 1: 28-34, Mei 2021 | 30

Nur'azni, et al/Media Eksakta 17(1) (C2021)

dari video pembelajaran fisika berbahasa kaili yang dihasilkan. video pembelajaran fisika berbahasa kaili dievaluasi juga untuk melihat sejauh mana media video pembelajaran bisa dan layak digunakan. Melalui evaluasi kelebihan dan kekurangan bisa diketahui dan sangat memungkinkan untuk dilakukan perbaikan sehingga pembelajaran media video pembelajaran ini menjadi lebih baik.

Setelah melakukan revisi desain, peneliti melakukan uji produk awal pada siswa SMP Negeri 1 Sindue untuk menguji kelayakan video pembelajaran fisika berbahasa kaili pada materi besaran fisika dan pengukurannya tersebut. Dan hasil uji coba menunjukkan bahwa media video pembelajaran berbahasa kaili yang dikembangkan layak untuk digunakan sebagai media video pembelajaran.

4. Implementation

Media video pembelajaran fisika berbahasa kaili yang telah validasi diujicobakan kepada 20 orang siswa. Setelah siswa mengikuti uji coba, selanjutnya siswa diminta untuk mengisi lembar kuisioner berupa tanggapan terhadap media video pembelajaran.

Penelitian ini bertempat di lingkungan SMP Negeri 1 Sindue yang berada di Desa Toaya Kecamatan Sindue Kabupaten Donggala. Waktu pelaksanaan penelitian pengembangan ini dilakukan mulai pada Senin 29 April 2019.

Subjek penelitian ini adalah siswa kelas VII yang fasih berbahasa kaili dialeg rai. Karena penelitian ini adalah penelitian dan pengembangan dengan uji terbatas, maka hanya sebagian saja siswa yang diambil sebagai subjek penelitian untuk menilai kelayakan media video pembelajaran fisika berbahasa kaili.

Instrumen penelitian yang digunakan pada penelitian ini adalah angket yang diberikan kepada ahli materi, ahli media, ahli bahasa dan agket guru mata pelajara Fisika dan siswa sebagai responden.

Teknik analisis yang digunakan untuk menganalisis data hasil validasi adalah perhitungan nilai rata-rata. Penentuan teknik analisis nilai rata-rata ini berdasarkan pendapat dari Arikunto [7] yang menyatakan bahwa untuk mengetahui peringkat nilai akhir pada setiap butir angket penelitian, jumlah nilai yang diperoleh dibagi dengan banyaknya responden yang menjawab angket penilaian tersebut. Rumus untuk menghitung nilai rata-rata adalah sebagai berikut.

$$
\bar{X}=\frac{\sum x}{n}
$$

Keterangan:

$\overline{\boldsymbol{X}} \quad$ : nilai rata-rata dalam tiap butir pernyataan

$\sum \boldsymbol{x}:$ jumlah nilai dari seluruh penilaian dalam tiap butir pernyataan

$\boldsymbol{n}$ : jumlah butir pernyataan

Mengubah skor rata-rata yang diperoleh ke dalam bentuk kualitatif berdasarkan Tabel 1 .

Tabel 1. Kriteria Nilai Produk

Skor Rata-Rata $\quad$ Kriteria

\begin{tabular}{cc}
\hline Skor Rata-Rata & Kriteria \\
\hline $3,25<\bar{X} \leqslant 4,00$ & Sangat baik (SB) \\
$2,50<\bar{X} \leqslant 3,25$ & Baik (B) \\
$1,75<\bar{X} \leqslant 2,50$ & Kurang (K) \\
$1,00 \leqslant \bar{X} \leqslant 1,75$ & Sangat Kurang (SK) \\
\hline
\end{tabular}

Analisis data respon siswa serupa dengan analisis kualitas penilaian produk. Rata-rata skor dari angket respon selanjutnya diubah ke dalam bentuk kualitatif berdasarkan Tabel 2.

Tabel 2. Kriteria Kategori Respon Siswa

\begin{tabular}{cc}
\hline Skor Rata-Rata & Kriteria \\
\hline $3,25<\bar{X} \leqslant 4,00$ & Sangat Setuju (SS) \\
$2,50<\bar{X} \leqslant 3,25$ & Setuju (S) \\
$1,75<\bar{X} \leqslant 2,50$ & Tidak Setuju (TS) \\
$1,00 \leqslant \bar{X} \leqslant 1,75$ & Sangat Tidak Setuju (STS) \\
\hline
\end{tabular}

Skor penilaian atau tingkat kelayakan baik setiap aspek maupun keseluruhan terhadap bahan ajar menggunakan Tabel 2, sebagai acuan penilaian data yang dihasilkan dari validitas ahli materi, guru mata pelajaran serta ujicoba pada siswa agar mempermudah dalam pemberian suatu kriteria nilai bahwa bahan ajar fisika materi suhu dan kalor berbasis android yang dikembangkan sudah layak atau belum untuk digunakan.

\section{HASIL DAN PEMBAHASAN}

\section{Hasil Penelitian}

1. Validasi Ahli Materi. Ahli materi adalah validator yang dipilih untuk menilai kelayakan dari aspek kurikulum, penyajian materi dan kebahasaan. Validasi dilakukan oleh seorang dosen pendidikan fisika. Secara umum validasi ahli materi dilakukan oleh ahli materi yaitu ibu Ni Made Wiwik Astuti, S.Pd, M.Ed selaku dosen program studi pendidikan fisika. Hasil yang diperoleh dari penilaian ahli materi dapat dilhat pada Tabel 3 .

Tabel 3. Hasil Validasi Aspek Kelayakan Materi

\begin{tabular}{|c|c|c|c|}
\hline No & Indikator & $\begin{array}{c}\text { Skor } \\
\text { Indikator }\end{array}$ & Klasifikasi \\
\hline 1 & $\begin{array}{l}\text { Kesesuaian isi bahan ajar } \\
\text { dengan kompetensi dasar } \\
\text { (KD) dan tujuan } \\
\text { pembelajaran. }\end{array}$ & 4,00 & $\begin{array}{c}\text { Sangat } \\
\text { Baik }\end{array}$ \\
\hline 2 & $\begin{array}{lll}\text { Kebenaran } & \text { konsep } & \text { maeri } \\
\text { ditinjau } & \text { dari } & \text { aspek } \\
\text { keilmuan. } & & \\
& & \end{array}$ & 4,00 & $\begin{array}{c}\text { Sangat } \\
\text { Baik }\end{array}$ \\
\hline 3 & $\begin{array}{l}\text { Penyajian apersepsi } \\
\text { mengingatkan siswa pada } \\
\text { materi sebelumnya. }\end{array}$ & 3,00 & Baik \\
\hline 4 & $\begin{array}{ll}\text { Kejelasan } & \text { topik } \\
\text { pembelajaran. } & \end{array}$ & 3,00 & Baik \\
\hline 5 & Cakupan materi & 3,00 & Baik \\
\hline 6 & Keruntutan materi & 2,00 & $\begin{array}{c}\text { Kurang } \\
\text { Baik }\end{array}$ \\
\hline 7 & Kesesuaian & 3,00 & Baik \\
\hline
\end{tabular}




\begin{tabular}{clcc}
\hline No & \multicolumn{1}{c}{ Indikator } & \multicolumn{1}{c}{$\begin{array}{c}\text { Skor } \\
\text { Indikator }\end{array}$} & Klasifikasi \\
\hline & $\begin{array}{l}\text { kesulitan dan keabstrakan } \\
\text { konsep dengan } \\
\text { perkembangan kognitif } \\
\text { siswa SMA kelas XI }\end{array}$ & & \\
8 & $\begin{array}{l}\text { Keterkaitan contoh materi } \\
\text { dengan kondisi yang ada } \\
\text { di lingkungan sekitar. }\end{array}$ & 4,00 & Sangat \\
Baik \\
Kejelasan contoh yang \\
diberikan
\end{tabular}

Tabel 4. Hasil Validasi Aspek Kelayakan Kebahasaan

\begin{tabular}{cccc}
\hline No & \multicolumn{1}{c}{ Indikator } & $\begin{array}{c}\text { Skor } \\
\text { Indikator }\end{array}$ & Klasifikasi \\
\cline { 1 - 2 } 1 & $\begin{array}{l}\text { Kemudahan memahami } \\
\text { alur materi melalui }\end{array}$ & 4,00 & Sangat Baik \\
$\begin{array}{l}\text { penggunaan bahasa. } \\
2\end{array}$ & $\begin{array}{l}\text { Kesantunan penggunaan } \\
\text { bahasa } \\
\text { Ketepatan teks dengan } \\
\text { materi. }\end{array}$ & 4,00 & Sangat Baik \\
Rata-rata & 3,00 & Baik \\
& & $\mathbf{3 , 7 0}$ & $\begin{array}{c}\text { Sangat } \\
\text { Baik }\end{array}$ \\
\hline
\end{tabular}

Tabel 5. Hasil Validasi Penyajian

\begin{tabular}{|c|c|c|c|}
\hline No & Indikator & $\begin{array}{c}\text { Skor } \\
\text { Indikator }\end{array}$ & Klasifikasi \\
\hline 1 & $\begin{array}{l}\text { Dukungan media } \\
\text { video Pembelajaran } \\
\text { terhadap keterlibatan } \\
\text { siswa pada proses } \\
\text { pembelajaran. }\end{array}$ & 4,00 & Sangat Baik \\
\hline 2 & $\begin{array}{l}\text { Penyajian gambar } \\
\text { tampilan } \\
\text { Kejelasan video yang } \\
\text { mendukung untuk } \\
\text { memahami materi }\end{array}$ & 4,00 & Sangat Baik \\
\hline & Rata-rata & 4,00 & $\begin{array}{l}\text { Sangat } \\
\text { Baik }\end{array}$ \\
\hline \multicolumn{4}{|c|}{$\begin{array}{l}\text { Tabel 6. Hasil Validasi Efek Media Video Terhadap } \\
\text { Strategi Pembelajaran }\end{array}$} \\
\hline No & Indikator & $\begin{array}{c}\text { Skor } \\
\text { Indikator }\end{array}$ & Klasifikasi \\
\hline 1 & $\begin{array}{l}\text { Kemudahan } \\
\text { penggunaan }\end{array}$ & 4,00 & Baik \\
\hline 2 & $\begin{array}{l}\text { Dukungan media Vieo } \\
\text { Pembelajaran bagi } \\
\text { kemandirian belajar } \\
\text { siswa. }\end{array}$ & 3,00 & Baik \\
\hline
\end{tabular}

Kemampuan Media

Video Pembelajaran

3 untuk meningkatkan

motivasi siswa dalam

3,00

Baik

mempelajari fisika.

Kemampuan Media

4 Video Pembelajaran

menambah

Baik

pengetahuan.

Kemampuan Media

5 Video Pembelajaran

memperluas wawasan siswa.

Rata-rata

Baik

3,20

Baik

Secara umum, hasil yang diperoleh dari penilaian ahli materi dapat dilihat pada Tabel 7

Tabel 7. Hasil Validasi Kelayakan Oleh Ahli Materi

\begin{tabular}{|c|c|c|c|}
\hline No & Aspek Penilaian & $\begin{array}{l}\text { Rata-rata } \\
\text { jumlah nilai }\end{array}$ & Kategori \\
\hline 1 & $\begin{array}{l}\text { Aspek Kelayakan } \\
\text { Materi }\end{array}$ & 3,50 & $\begin{array}{l}\text { Sangat } \\
\text { Baik }\end{array}$ \\
\hline 2 & $\begin{array}{l}\text { Kelayakan } \\
\text { Kebahasaan }\end{array}$ & 3,70 & $\begin{array}{l}\text { Sangat } \\
\text { Baik }\end{array}$ \\
\hline 3 & $\begin{array}{l}\text { Kelayakan } \\
\text { Penyajian }\end{array}$ & 4,00 & $\begin{array}{l}\text { Sangat } \\
\text { Baik }\end{array}$ \\
\hline 4 & $\begin{array}{l}\text { Kelayakan } \quad \begin{array}{r}\text { Efek } \\
\text { media } \\
\text { pembelajaran }\end{array} \\
\text { Terhadap Strategi } \\
\text { Pembelajaran }\end{array}$ & 3,20 & $\begin{array}{l}\text { Sangat } \\
\text { Baik }\end{array}$ \\
\hline & Total & 3.60 & $\begin{array}{c}\text { Sangat } \\
\text { baik }\end{array}$ \\
\hline
\end{tabular}

Berdasarkan data tersebut, penilaian yang diberikan oleh ahli materi terhadap video berbahasa kaili dapat diinterprestasikan sangat baik yang menunjukkan bahwa media video pembelajaran layak diujicobakan.

Dari hasil validasi ahli materi terhadap video yang dikembangkan didapatkan beberapa kekurangan. Adapun saran yang dijadikan sebagai perbaikan antara lain :

Komentar oleh ahli materi:

Materi dalam video sudah mampu mendorong curiosity siswa. Namun siswa masih susah untuk belajar mandiri karena keterbatasan materi yang di video. Contoh, penjelasan tentag besaran fisika kebanyakan masih terbatas pada tinggi/panjang. Belum ada penjelasan tentang besaran yang lain dan satuannya.

2. Hasil Uji Kelayakan Oleh Guru. Untuk mengetahui kelayakan penggunaan aplikasi oleh guru, maka guru diberi lembar penilaian yang berkaitan dengan aplikasi. Hasil penilaian oleh guru dapat dilihat pada Tabel 8 .

Tabel 8. Hasil Uji Kelayakan Kegrafikan

\begin{tabular}{clcc}
\hline No & \multicolumn{1}{c}{ Indikator } & $\begin{array}{c}\text { Skor } \\
\text { Indikator }\end{array}$ & Klasifikasi \\
\hline 1 & Kurikulum & 3,00 & Baik \\
2 & Penyajian materi & 3,00 & Baik \\
\hline
\end{tabular}




\begin{tabular}{rrrr}
\hline 4 & Kebahasaan & 3,00 & Baik \\
Rata-rata & $\mathbf{3 , 4 5}$ & Baik \\
\hline
\end{tabular}

Berdasarkan data tersebut, penilaian yang diberikan oleh praktisi pembelajaran (Guru) terhadap video pembelajaran fisika berbahasa kaili dapat diinterprestasikan sangat baik yang menunjukkan bahwa video pembelajaran berbahasa kaili layak digunakan sebagai media pembelajaran

Komentar Guru:

Selain untuk menggunakan kata "Iko" bisa diganti dengan kata yang lebih halus seperti "komiu", agar bisa lebih mendidik anak-anak supaya bisa berbicara sopan dan santun, baik dengan teman, orang tua dan masyarakat pada umumnya.

3. Hasil Angket Respon Siswa. Pada tahap ini dilakukan uji coba terbatas pada 20 siswa di SMP Negeri 1 Sindue. Hasil uji coba yang dilakukan menunjukkan bahwa media video pembelajaran berbahasa kaili yang dikembangkan layak untuk digunakan sebagai media video pembelajaran. Hal tersebut dapat dilihat pada Tabel 9.

Tabel 9. Hasil Analisis Rata-Rata Penilaian Respon Siswa

\begin{tabular}{|c|c|c|}
\hline No. & Pernyataan & $\begin{array}{c}\text { Skor } \\
\text { rata-rata }\end{array}$ \\
\hline 1 & $\begin{array}{l}\text { Ilustrasi yang diberikan dalam } \\
\text { media video pembelajaran sangat } \\
\text { jelas dan berkaitan dengan } \\
\text { kehidupan sehari-hari }\end{array}$ & 3,70 \\
\hline 2 & 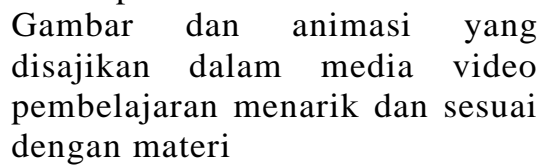 & 3,65 \\
\hline 3 & $\begin{array}{l}\text { Video yang disajikan dapat } \\
\text { meningkatkan semangat belajar }\end{array}$ & 3.65 \\
\hline 4 & $\begin{array}{l}\text { Media video pembelajaran } \\
\text { pembelajaran ini memudahkan } \\
\text { memahahi materi melalui video } \\
\text { dan bahasa daerah }\end{array}$ & 3.70 \\
\hline 5 & $\begin{array}{l}\text { Bahasa daerah yang digunakan } \\
\text { mudah dipahami }\end{array}$ & 3.35 \\
\hline 6 & $\begin{array}{l}\text { Dapat menjadi alternative sumber } \\
\text { belajar }\end{array}$ & 3.75 \\
\hline 7 & $\begin{array}{l}\text { Menggunakan media video } \\
\text { pembelajaran ini dapat membuat } \\
\text { belajar Fisika tidak membosankan }\end{array}$ & 3.70 \\
\hline 8 & Gambar yang disajikan menarik & 3.50 \\
\hline 9 & $\begin{array}{l}\text { Media video pembelajaran ini } \\
\text { mudah untuk digunakan }\end{array}$ & 3.50 \\
\hline 10 & $\begin{array}{l}\text { Media video pembelajaran ini } \\
\text { membuat saya bisa belajar fisika } \\
\text { secara mandiri }\end{array}$ & 3.50 \\
\hline & $\begin{array}{llr}\text { Media video } & \text { pembelajaran } \\
\text { memotivasi } & \text { saya } & \text { untuk }\end{array}$ & 3,60 \\
\hline 11 & $\begin{array}{l}\text { mempelajari fisika khususnya } \\
\text { pokok Besaran fisika dan } \\
\text { pengukurannya }\end{array}$ & 3,70 \\
\hline 12 & $\begin{array}{l}\text { Media video pembelajaran ini } \\
\text { memperluas wawasan saya. }\end{array}$ & 3.70 \\
\hline 13 & Tulisan yang digunakan mudah & 3,45 \\
\hline
\end{tabular}

untuk dibaca

14 Kesesuaian gambar dan materi membuat saya lebih semangat

15 Tampilan/desain media menarik

Skor

Tabel 10. Hasil Analisis Rata-Rata Penilaian Siswa Kelas Eksperimen

\begin{tabular}{|c|c|c|}
\hline No. & Pernyataan & $\begin{array}{c}\text { Skor } \\
\text { rata-rata }\end{array}$ \\
\hline 1 & $\begin{array}{l}\text { Menyelesaikan tugas yang } \\
\text { diberikan sangat mendorong } \\
\text { supaya aktif daya } \\
\text { pembelajaran }\end{array}$ & 3,50 \\
\hline 2 & $\begin{array}{l}\text { Mendengarkan dan memperhatikan } \\
\text { apabila guru sedang menjelaskan } \\
\text { materi }\end{array}$ & 3,60 \\
\hline 3 & $\begin{array}{l}\text { Memberikan siswa kesempatan } \\
\text { mengeluarkan pendapat pada saat } \\
\text { materi berlangsung }\end{array}$ & 3.20 \\
\hline 4 & $\begin{array}{l}\text { Siswa menangcungka tangan untuk } \\
\text { maju mengerjakan depan kelas }\end{array}$ & 3.30 \\
\hline 5 & $\begin{array}{l}\text { Guru mampu menyampaikan materi } \\
\text { agar siswa paham }\end{array}$ & 3.00 \\
\hline 6 & $\begin{array}{l}\text { Siswa terlibat dalam kegiatan tanya } \\
\text { jawab dalam kelas }\end{array}$ & 3.70 \\
\hline 7 & $\begin{array}{l}\text { Siswa mudah memahami serta } \\
\text { tertarik ketika proses belajar } \\
\text { mengajar berlangsung. }\end{array}$ & 3.80 \\
\hline & Skor & 3,44 \\
\hline
\end{tabular}

Tabel 11. Hasil Analisis Rata-Rata Penilaian Siswa Kelas Eksperimen

\begin{tabular}{|c|c|c|}
\hline No. & Pernyataan & $\begin{array}{c}\text { Skor } \\
\text { rata-rata }\end{array}$ \\
\hline 1 & 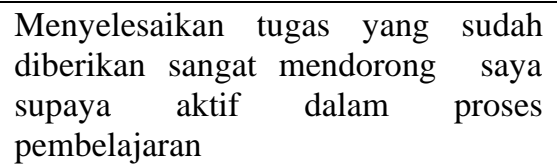 & 3.10 \\
\hline 2 & $\begin{array}{l}\text { Mendengarkan dan memperhatikan } \\
\text { apabila guru sedang menjelaskan } \\
\text { materi }\end{array}$ & 3.40 \\
\hline 3 & $\begin{array}{l}\text { Memberikan siswa kesempatan } \\
\text { mengeluarkan pendapat pada saat } \\
\text { materi berlangsung }\end{array}$ & 3.60 \\
\hline 4 & $\begin{array}{l}\text { Siswa menangcungka tangan untuk } \\
\text { maju mengerjakan depan kelas }\end{array}$ & 2.90 \\
\hline 5 & $\begin{array}{l}\text { Guru mampu menyampaikan materi } \\
\text { agar siswa paham }\end{array}$ & 3.50 \\
\hline 6 & $\begin{array}{l}\text { Siswa terlibat dalam kegiatan tanya } \\
\text { jawab dalam kelas }\end{array}$ & 3.60 \\
\hline 7 & $\begin{array}{l}\text { Siswa mudah memahami serta } \\
\text { tertarik ketika proses belajar } \\
\text { mengajar berlangsung. }\end{array}$ & 3.60 \\
\hline & Skor & 3,39 \\
\hline
\end{tabular}




\section{Pembahasan}

Pengembangan media video pembelajaran fisika berbahasa kaili melalui 4 tahap yaitu 1. Analysis, 2. Design, 3. Development, 4. Implementation. Proses pembuatan dilaksanakan secara bertahap dan untuk menghasilkan media pembelajaran yang layak dilakukan serangkaian validasi ahli materi, validasi ahli media, validasi ahli bahasa, uji kelayakan praktisi pembelajaran (guru) dan 20 orang siswa kelas VII hasanudin SMPN 1 Sindue. Semua rangkaian tersebut dimaksudkan untuk memperoleh data yang selanjutnya dilaksanakan revisi atau perbaikan agar tercapai media pembelajaran yang layak dan bermanfaat bagi penggunanya.

Berdasarkan penilaian ahli materi yang oleh dosen pendidikan fisika yaitu Ni Made Wiwik Astuti, S.Pd., M.Ed, aspek yang dinilai dari video meliputi kelayakan materi, kebahasaan, penyajian, dan efek media terhadap strategi pembelajaran. Secara keseluruhan, didapatkan jumlah ratarata nilai 3,6. Berdasarkan data tersebut, penilaian yang diberikan oleh ahli materi terhadap video pembelajaran fisika berbahasa kaili ini dapat diinterprestasikan sangat baik sehingga layak diujicobakan.

Selanjutnya, hasil penilaian ahli bahasa yang dilakukan oleh dosen bahasa indonesia yaitu Dr. H. Gazali, M.Pd, aspek yang dinilai dari video pembelajaran fisika berbahasa kaili ini meliputi kelayakan kebahasaan. Sehingga, jika dianalisis secara keseluruhan akan diperoleh nilai rata-rata 3,7 . Berdasarkan data tersebut, penilaian yang diberikan oleh ahli bahasa terhadap video pembelajaran fisika berbahasa ini dapat diinterprestasikan sangat baik sehingga layak diujicobakan.

Selanjutnya, hasil penilaian ahli media yang dilakukan oleh dosen pendidikan fisika yaitu Wahyuni N. Laratu, S.Pd., M.Pd, aspek yang dinilai dari video pembelajaran fisika berbahasa kaili ini meliputi kelayakan kebahasaan, tampilan visual, efek media terhadap strategi pembelajaran dan tampilan perangkat lunak. Sehingga, jika dianalisis secara keseluruhan akan diperoleh nilai rata-rata 3,5 . Berdasarkan data tersebut, penilaian yang diberikan oleh ahli media terhadap video pembelajaran fisika berbahasa kaili ini dapat diinterprestasikan sangat baik serta dilakukan revisi sesuai saran oleh ahli media sehingga layak diujicobakan.

Setelah dinyatakan layak oleh ahli materi dan ahli media maka media video pembelajaran fisika berbahasa kaili ini diuji cobakan dalam uji kelayakan praktisi pembelajaran (guru) dan uji terbatas. Uji kelayakan dilakukan oleh seorang guru SMPN 1 Sindue, Ibu Setyawati, S.Pd aspek yang dinilai dari video pembelajaran fisika berbahasa kaili ini meliputi kurikulum, penyajian materi dan kebahasaan. Rata-rata penilaian keseluruhan dari praktisi pembelajaran (guru) yaitu 3,0 . Berdasarkan data tersebut, penilaian yang diberikan oleh praktisi.

Selanjutnya, dilakukan uji coba terbatas dengan tujuan untuk mengetahui penilaian siswa terhadap produk pengembangan yang telah dihasilkan, berupa video pembelajaran fisika berbahasa kaili. Media pembelajaran hasil pengembangan diujikan dalam uji coba lapangan skala terbatas kepada 20 orang siswa. Tujuan pelaksanaan uji coba lapangan skala terbatas adalah untuk mendapatkan gambaran respon siswa terhadap produk yang sedang dikembangkan.
Pada penelitian ini, siswa memberi penilaian terhadap materi, bahasa, dan ketertarikan mereka menggunakan media pembelajaran tersebut. Hasil analisis penilaian siswa terhadap media video pembelajaran fisika materi besaran fisika dan pengukurannya yang dikembangkan disajikan sebagai berikut: Oleh karena tipe pernyataannya bersifat positif, maka nilai (score) untuk tiap pilihan jawabannya adalah sebagai berikut :4; Sangat setuju, 3; Setuju, 2; Tidak setuju, 1; Sangat tidak setuju.

Uji terbatas dilakukan pada siswa kelas VII ${ }^{\mathrm{D}}$ Hasanudin di SMPN 1 Sindue, dimana siswa diberikan angket yang berisi 15 item pernyataan. Setelah melakukan analisis terhadap angket yang diberikan kepada 20 orang siswa, didapatkan skor nilai rata-rata sebesar 3,63. Penilaian tersebut dapat diinterprestasikan bahwa siswa sangat setuju jika video pembelajaran fisika berbahasa kaili tersebut digunakan dalam proses pembelajaran di kelas baik secara terbimbing maupun mandiri.

Penilaian dari siswa yang positif ini, besar kemungkinan dikarenakan sebelumnya di sekolah tersebut masih kurang menggunakan media video pembelajaran, apalagi dijelaskan dengan menggunakan bahasa daerah mereka. Sehingga hal tersebut membuat mereka merasa tidak bosan dan cepat paham dengan video pembelajaran fisika yang ditampilkan didepan kelas dengan berbantuan infokus dan pengeras suara. Seperti komentar yang diberikan oleh Sitti Fadillah dalam kolom komentar angket yang dibagikan "Menurut saya pembelajaran ini layak untuk di tonton karena kita dapat memahami besaran fisika dan pengukurannya dengan lebih mudah apalagi pembelajaran ini menggunakan bahasa kaili dan komentar oleh Suriani dalam kolom komentar yaitu saya sangat senang menonton video pembelajaran fisika ini karena videonya membuat saya sangat termotivasi untuk mempelajari fisika apalagi video ini menggunakan bahasa kaili (bahasa daerah saya) sehingga saya semakin mudah dalam memahami pelajaran IPA Fisika yang selama ini saya anggap sulit".

\section{KESIMPULAN}

\section{Kesimpulan}

Dari penelitian dan pembahasan diatas, maka dapat di simpulkan bahwa perangkat lunak berupa video pembelajaran fisika berbahasa kaili yang dihasilkan dapat digunakan membantu pembelajaran mata pelajaran fisika pada materi besaran fisika dan pengukurannya. Hasil dari uji ahli materi, ahli bahasa dan ahli media dalam mengukur kualitas kelayakan media video pembelajaran fisika berbahasa kaili pada materi besaran fisika dan pengukurannya memperoleh kategori layak. Sedangkan dari pendapat dari siswa berjumlah 20 orang pada kelas VII di SMP Negeri 1 Sindue sebagai pengguna media video pembelajaran fisika berbahasa kaili juga memperoleh kategori layak, hal tersebut terlihat dari hasil penelitian yang didapat dalam mengukur kelayakan media dari sisi pengguna oleh siswa dalam uji coba lapangan skala kecil dan uji coba lapangan skala besar. 


\section{Saran}

Diharapkan adanya penelitian lebih lanjut terhadap efektivitas penggunaan media video pembelajaran fisika berbahasa kaili pada kelas VII di SMP Negeri 1 Sindue, sehingga dapat meningkatkan prestasi siswa.

\section{REFFERENSI}

[1] E. Widyhastuti." Pengembangan multimedia interaktif unggah-unggah bahasa jawa untuk kelas $\mathrm{v}$ sekolah dasar”. Jurnal Pendidikan Guru Sekolah Dasar. Edisi 3 Tahun ke-5, 2016.

[2] Sarmin. "Sistem morfoligi nomina dalam bahasa kaili susu”. Jurnal Humanika .No. 15, Vol.3, 2015.

[3] Kalinda, dkk. "Pengembangan modul pembelajaran Fisika berbasis Inkuiri Terbimbing pada Materi Suhu dan Perubahannya" Jurnal Pembelajaran Fisika. Vol. 3, No. 3, 2015

[4] P. Ayuningtyas, dkk. "Pengembangan perangkat pembelajaran fisika dengan model inkuiri terbimbing untuk melatihkan keterampilan proses sains siswa pada materi fluida statis". Pendidikan Sains Pascasarjana Universitas Negeri Surabaya. Vol. 4, No. 2, 2015.

[5] Putra, dkk. "Pengembangan media vidio pembelajaran dengan model Addie pada pembelajaran bahasa inggris di SDN 1 Selat". e-Jurnal Edutech Universitas Pendidikan Ganesha Jurusan Teknologi Pendidikan (vol: 2 No: 1, 2014.

[6] Sugiyono. Metode Penelitian Kuantitatif, Kualitatif dan $R \& D$, Bandung: Alfabeta,2010.

[7] S.Arikunto. Prosedur Penelitian: Suatu Pendekatan Praktik. Jakarta: Rineka Cipta, 2006 